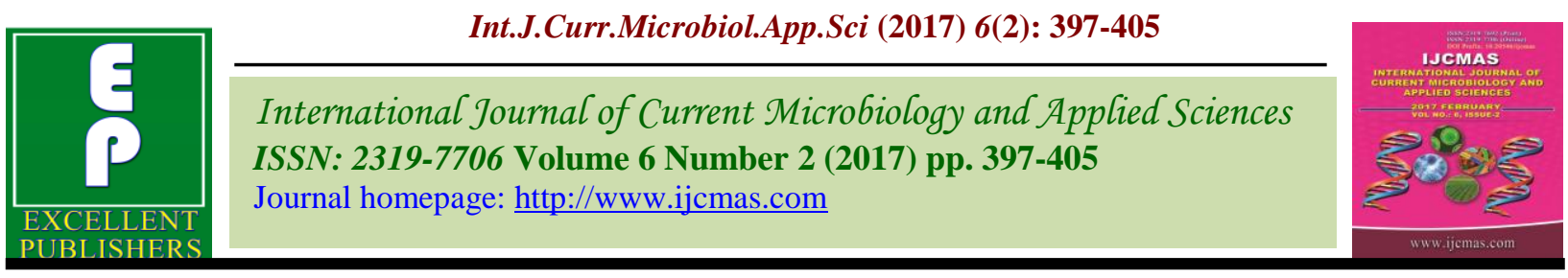

Original Research Article

http://dx.doi.org/10.20546/ijcmas.2017.602.044

\title{
Alkaliphilism and Carbonate Transport in Alkaliphilic Cyanobacteria (Phormidium sp.) Isolated from Alkaline Lake Lonar, India
}

\author{
Devendra Deshmukh ${ }^{1} *$ and Pravin Puranik ${ }^{2}$ \\ ${ }^{1}$ Department of Microbiology, NKSPT's Arts, Science and Commerce College, \\ Badnapur, Jalna, Maharashtra, India \\ ${ }^{2}$ Department of Biotechnology, School of Life Sciences, North Maharashtra University, \\ Jalgaon, Maharashtra, India \\ *Corresponding author
}

\section{A B S T R A C T}

\begin{tabular}{|c|}
\hline Keywords \\
\hline $\begin{array}{l}\text { Cyanobacteria, } \\
\text { Lonar Lake, } \\
\text { Alkaliphiles, } \\
\text { Sodium carbonate, } \\
\text { FTIR, Phormidium. }\end{array}$ \\
\hline Article Info \\
\hline $\begin{array}{l}\text { Accepted: } \\
\text { 15 January } 2017 \\
\text { Available Online: } \\
\text { 10 February } 2017\end{array}$ \\
\hline
\end{tabular}

\section{Keywords}

Cyanobacteria, Lonar Lake, Alkaliphiles, Sodium carbonate,

\begin{abstract}
The alkaline lake Lonar is situated in buldhana District of Maharashtra, India. The lake is around 50-60 thousand years old and water is alkaline ( $\mathrm{pH} \mathrm{10.36).} \mathrm{It} \mathrm{is} \mathrm{the} \mathrm{third} \mathrm{largest}$ meteorite crater in basaltic rock in the world, with a diameter of $1,800 \mathrm{~m}$. While Lake Bosmatvi in Ghana, has a diameter of 10,000 m and lake New Quebec in Canada with a diameter of $3,500 \mathrm{~m}$. The alkaliphilic cyanobacteria in this lake have developed mechanisms for their survival in alkaline environments. The alkaliphilic cyanobacteria Phormidium sp. isolated from Lonar lake was able to tolerate a concentration of $1 \mathrm{M}$ $\mathrm{Na}_{2} \mathrm{CO}_{3}$ this reveled its existence in the lake throughout the year. In order to reveal its carbonate transport system a variation of $\mathrm{NaCl}$ along with $\mathrm{Na}_{2} \mathrm{CO}_{3}$ was done which resulted that a small amount of $\mathrm{NaCl}$ is need for the transport of carbonates. The cyanobacterial sheath under carbonate stress was isolated and FTIR of the sheath material was done. The FTIR spectra gave a characteristic features of the sheath isolated from Phormidium sp at $1 \mathrm{M} \mathrm{Na}_{2} \mathrm{CO}_{3}$ concentration between the range of $1000-3000 \mathrm{~cm}^{-1}$. It was established that the investigated cyanobacterium possessed two carbonate transport systems operational at $\mathrm{pH} 9$ and 10. This reflects the adaptation of the cyanobacteria to seasonal variation in the alkaline- saline lake Lonar. Thus the alkaliphilism or adaptation of cyanobacteria in the alkaline lake lonar was understood which depends on the seasonal salinization and desalinization cycles.
\end{abstract}

\section{Introduction}

A characteristic feature of the majority of soda lakes is the presence of permanent or seasonal colored blooms of phototropic microorganisms. Extreme alkaliphiles live in soils laden with soda or in soda lakes where the $\mathrm{pH}$ can rise to 12 . The soda lakes are the most stable and productive naturally occurring alkaline environments in the world, with $\mathrm{pH}$ values greater than 10 (Jhingran and Rao, 1954). One of the striking facts about soda lakes is that, despite apparently inhospitable caustic conditions, these environments are extremely productive because of high ambient temperatures, high light intensities, and effectively unlimited supplies of $\mathrm{CO}_{2}$ via the $\mathrm{HCO}_{3}{ }^{-} / \mathrm{CO}_{3}{ }^{-} / \mathrm{CO}_{2}$ equilibrium (Grant and Tindall, 1980).

The alkaline lake Lonar is situated in buldhana District of Maharashtra, India. The 
lake is around 50-60 thousand years old and water is alkaline ( $\mathrm{pH}$ 10.36). It is the third largest meteorite crater in basaltic rock in the world, with a diameter of $1,800 \mathrm{~m}$. While Lake Bosmatvi in Ghana, has a diameter of $10,000 \mathrm{~m}$ and lake New Quebec in Canada with a diameter of $3,500 \mathrm{~m}$ (Castanier et al., 1999). Soda lakes are characterized by the presence of large amount of sodium carbonate (or complexes of these salts) formed by evaporative concentration under particular condition of geology, geography, and climate (Grant, 2004). The soda lake habitats often have a combination of $\mathrm{Ca}^{2+}$ and carbonate levels. The higher the levels of $\mathrm{Ca}^{2+}$ than carbonates lowers alkaline conditions and lower the level of $\mathrm{Ca}^{2+}$ than carbonates higher alkalinity develops (Giordane et al., 2005).

The saline alkaline Lake Lonar experiences different periods of annual cycles which results in change in carbonate concentration and $\mathrm{pH}$ as well. The main aim of the study was to elucidate the effect of these factors on the Phormidium sp. isolated from Lonar Lake.

\section{Materials and Methods}

\section{Organism and culture conditions}

The cyanobacterium Phormidium sp. used in this study was isolated from the water sample of alkaline Lake Lonar. The identification of the blue-green algae was done as per the monograph, 'Cyanophyta' (Desikachary, 1959). The cyanobacterium was maintained on BG-11 media (Kaushik, 1987). Each liter of BG-11 medium contains $\left(\mathrm{g} \mathrm{L}^{-1}\right)$ of $\mathrm{NaNO}_{3}$, $1.5 ; \mathrm{K}_{2} \mathrm{HPO}_{4}, \quad 0.04 ; \quad \mathrm{MgSO}_{4} 7 \mathrm{H}_{2} \mathrm{O}, 0.075 ;$ $\mathrm{CaCl}_{2} 2 \mathrm{H}_{2} \mathrm{O}$, 0.036; citric acid, 0.006; ferric ammonium citrate, 0.006; EDTA, 0.001; $\mathrm{Na}_{2} \mathrm{CO}_{3}, 0.02$ and $1 \mathrm{~mL}$ of trace solution $\mathrm{A}_{5}$ containing $\left(\mathrm{g} \mathrm{L}^{-1}\right)$ of $\mathrm{H}_{3} \mathrm{BO}_{3}, 2.86 ; \mathrm{MnCl}_{2}$, 1.81; $\mathrm{ZnSO}_{4} 7 \mathrm{H}_{2} \mathrm{O}, 0.222 ; \mathrm{Na}_{2} \mathrm{MoO}_{4} 2 \mathrm{H}_{2} \mathrm{O}$, 0.39; $\quad \mathrm{CuSO}_{4} .5 \mathrm{H}_{2} \mathrm{O} ; \quad 0.079 \quad$ and $\mathrm{Co}\left(\mathrm{NO}_{3}\right)_{2} \cdot 6 \mathrm{H}_{2} \mathrm{O}, 0.0494$. The $\mathrm{pH}$ of the media was adjusted at 10.36 (lake water $\mathrm{pH}$ ). The flask was exposed to a light intensity of 12001500 lux with a light/dark cycle of $16 / 8 \mathrm{~h}$ at $24 \pm 2{ }^{\circ} \mathrm{C}$.

\section{Tolerance to carbonates}

The cyanobacterium Phormidium sp. was tested for its tolerance to carbonates in BG11. A series of flasks containing sterile growth medium amended with increasing carbonate concentrations $(0.2-1 \mathrm{M})$ were inoculated with equal inoculum. The bottles were incubated at $24 \pm 2^{\circ} \mathrm{C}$ for 15 days. The carbonate tolerance was judged on the basis of visible growth.

\section{Effect of $\mathrm{NaCl}$ with carbonates}

In order to elucidate the effect of carbonate concentration on the physiology of the Phormidium sp., it was varied with the $\mathrm{NaCl}$ concentration. A combination of sodium carbonate along with sodium chloride was prepared in such a way that the total molarity of the medium remains at the level of $1 \mathrm{M}$. The flasks were incubated for 15 days at $24 \pm 2{ }^{\circ} \mathrm{C}$. After incubation the flasks were harvested, chlorophyll a and phycocyanin content was measured (Kaushik, 1987).

\section{Isolation of sheath}

The sheath was isolated as according to procedure described by Struart and Ando (1997). The filamentous cyanobacterium Phormidium sp was harvested and washed twice in $20 \mathrm{mM}$ ammonium acetate buffer ( $\mathrm{pH}$ 7.0). The filaments were resuspended in the buffer and broken by ultrasonication (Sonics and Materials Inc., USA). The crude sheath was isolated by centrifugation (15 $\mathrm{min}$ at $750 \mathrm{X}$ g) (Sorvall, USA, Model RC2). Further purification of the sheath was done with lysozyme. The enzyme was added to a protein/sheath ratio of 1 : 5 (dry weight/wet 
weight) and the digestion was performed at $37^{\circ} \mathrm{C}$ for $24 \mathrm{~h}$. After incubation the sheath was washed and extracted with sodium dodecyl sulphate (SDS; 4\% [wt/vol] in acetate buffer at $60^{\circ} \mathrm{C}$ for $\left.15 \mathrm{~min}\right)$. Finally the sheathed material was repeatedly washed with distilled water.

\section{FTIR spectroscopy}

In order to study the functional group of the isolated sheath under carbonate stress the spectroscopic analysis of the purified sheath was done by means of Fourier transform infrared (FTIR) spectroscopy. About $50 \mathrm{mg}$ of sheath material was used for the analysis. The spectra were recorded using Nicolet 380 FTIR spectrometer in the wavelength of 500-4000 nm.

\section{Effect of pH}

In order to reveal the transport systems in the lonar lake isolate the culture was exposed to a $\mathrm{pH}$ range of 8 to 12 keeping the concentration of carbonate to $1 \mathrm{M}$ in each flask. The flasks were incubated for 15 days at $24 \pm 2^{\circ} \mathrm{C}$.After incubation the flask were harvested and the remaining concentration of carbonates in each flask was measured (APHA, 1995).

\section{Results and Discussion}

The cyanobacteria are globally important contributors to the biogeochemical cycling of carbon and to primary productivity. The ability of this diverse group of photoautotrophs to efficiently assimilate $\mathrm{CO}_{2}$ from the environment relies upon the concurrent activity of a biophysical $\mathrm{CO}_{2-}$ concentrating mechanism (CCM) (Badger et al., 2006, Grarcia-Pichel, 1998, Joshi et al., 2008). Calcium carbonate $\left(\mathrm{CaCO}_{3}\right)$ precipitation is a common phenomenon found in environments such as marine water, freshwater, and soils (Douglas and Beveridge, 1998). It is a rather straightforward chemical process governed by four key factors: (1) the calcium $\left(\mathrm{Ca}_{2}{ }^{+}\right)$concentration, (2) the concentration dissolved inorganic carbon (DIC), (3) the $\mathrm{pH}\left(\mathrm{pK}_{2}(\mathrm{CO})=10.3\right.$ at $\left.25^{\circ} \mathrm{C}\right)$ and (4) the availability of nucleation sites (Castanier et al., 1999; Kile et al., 2000). Numerous different bacterial species have previously been detected and assumed to be associated with natural carbonate precipitates from diverse environments. The primary role of bacteria in the precipitation process has subsequently been ascribed to their ability to create an alkaline environment (high $\mathrm{pH}$ and [DIC] increase) through various physiological activities (Douglas and Beveridge, 1998; Castanier et al., 1999). Although microbiological carbonate precipitation (MCP) has been investigated extensively both in natural environments and under defined laboratory conditions, the exact mechanisms of precipitation and the function of this process within the microbial ecology of the precipitating organism remains unresolved (Ferrer et al., 1988; Rivadeneyra et al., 1994; Yates and Robbins, 1999). Microbial associations with natural carbonate deposits have been described for seawater (Morita, 1980), saline lakes (Douglas and Beveridge, 1998), soils (Boquet et al., 1973) and geological formations (Peckman, 1999). The formation of alkalinity in the soda lake environment requires a combination of geographical, topographical and climatic conditions: firstly, the presence of geological conditions which favour the formation of alkaline drainage waters; secondly, suitable topography which restricts surface outflow from the drainage basin; and thirdly, climatic conditions conducive to evaporative concentration. Such conditions are found in arid and semi-arid zones of tropical or subtropical areas (Ulukanli and Digrak, 2002).

The Buldhana district of Maharashtra receives rains through the south west monsoon (from June to September). The average rainfall is 
about 500 to $900 \mathrm{~mm}$, the climate is dry and hot. The lake water is alkaline, having an average $\mathrm{pH}$ of $9.0-10.0$. Alkalinity of the lake is attributed to the high content of sodium carbonate (Jhingran and Rao, 1954). Previous reports of chemical analysis of Lonar lake suggest that lake water is highly alkaline and rich in various salts, carbonate and bicarbonate (Thakker and Ranade, 2002; Joshi et al., 2008. The alkaline lake lonar experiences a significant variability of $\mathrm{pH}$ (Fig. 1) and specifically during the rainy season as the $\mathrm{pH}$ starts to fall due to shift in the carbonate/ bicarbonate equilibrium. Generally during the rainy season in natural environments there is a decrease in $\mathrm{pH}$ by approximately 2.5 units (Garcia-Pichel et al., 1998).

The Phormidium sp.isolated from the alkaline lake Lonar was able to tolerate a concentration of $1 \mathrm{M} \quad \mathrm{Na}_{2} \mathrm{CO}_{3}$. At this concentration of $1 \mathrm{M}$ the Phormidium sp. was well adapted to the media as compared to lower concentration of $\mathrm{Na}_{2} \mathrm{CO}_{3}$.

$\mathrm{Na}^{+}$ions play an important role in transportation of constituents across the cell membrane.

Raven (1970) suggested that if the rate of photosynthesis by an alga is markedly higher at an alkaline $\mathrm{pH}$, for a given $\mathrm{CO}_{2}$ concentration, than at a more acid $\mathrm{pH}$ it can be concluded that the bicarbonate ion crosses the cell membrane and contributes $\mathrm{C}$ for photosynthesis. Miller et al., (1990) found that $\mathrm{Na}^{+}$is required for growth, photosynthesis and $\mathrm{pH}$ regulation in alkali tolerant cyanobacterium Synechococcus leopoliensis. In the present study the effect of $\mathrm{NaCl}$ on the carbonate transport was elucidated keeping the total concentration in the medium to $1 \mathrm{M}$. The Chl.a and phycocyanin content decreased as the concentration of $\mathrm{NaCl}$ increased than the concentration of $\mathrm{Na}_{2} \mathrm{CO}_{3}$ and vice-versa (Fig. 2 and 3). These result suggested that for the transportation of carbonates a very less amount of $\mathrm{NaCl}$ is needed, similar reports were obtained by Mikhodyuk et al., (2008) using the cyanobacterium Euhalothece sp isolated from Lake Magadi.

The FTIR analysis showed different bands in the range of 500-4000 nm (Fig. 4). The most characteristic features of the sheath isolated from Phormidium sp at $1 \mathrm{M} \quad \mathrm{Na}_{2} \mathrm{CO}_{3}$ concentration was observed between the range of $1000-3000 \mathrm{~cm}^{-1}$.

The spectrum of the purified sheath was dominated by the amide I feature at $\sim 1658.97$ and $1641.08 \mathrm{~cm}^{-1}$ (band 5 and 6, Table 1). This band is sensitive to the protein's secondary structure, to ligand interactions and to its folding characteristics (Zeroual et al., 1995); Brandenburg and Seydel, (1996); Panick and Winter, (2000). Some lipid vibrations can be found between 2800- 3000 $\mathrm{cm}^{-1}$ (bands 3 and 4 Table 1). These distinctive bands at 2851.21 and $2920.23 \mathrm{~cm}^{-1}$ correspond to the symmetric and asymmetric vibrations of $\mathrm{CH}_{2}$ methyl and $\mathrm{CH}_{3}$ methylene groups.

The purified sheath of Phormidium sp showed a prominent features corresponding to complex carbohydrates. For Phormidium sp, the carbohydrate bands are the main distinguishing features in the "fingerprint' region (1500 - $600 \mathrm{~cm}^{-1}$ ) (Diem, M, 1993; Stuart and Ando, 1997). These features exhibited characteristic C-O derived carbohydrate absorption bands in the wavenumbers between 1300 and $1000 \mathrm{~cm}^{-1}$ (bands 8 and 9, Table 1). At the wavenumbers between 500 and $1000 \mathrm{~cm}^{-1}$, some additional weak bands were observed.

Several transport systems with different $\mathrm{pH}$ optima mediates the process of carbonate transport in cyanobacteria (Badger et al., 
2006).

Table.1 Frequency and band assignment for FTIR spectra derived from Phormidium sp. purified sheath at $1 \mathrm{M} \mathrm{Na}_{2} \mathrm{CO}_{3}$

\begin{tabular}{|c|c|c|c|c|}
\hline Band & $\begin{array}{l}\text { Wavenumber } \\
\left(\mathrm{cm}^{-1}\right)\end{array}$ & Assignments & $\begin{array}{l}\text { Main group with } \\
\text { source }\end{array}$ & Comment \\
\hline 1 & 3532.98 & $\begin{array}{l}\text { (Str)O-H and } \\
\text { (str) N-H }\end{array}$ & Water $^{(4,11)}$ & Water/Amide \\
\hline 2. & 3350.69 & $\begin{array}{l}\text { (Str)O-H and } \\
\text { (str) N-H }\end{array}$ & Water $^{(4,11)}$ & Water/Amide \\
\hline 3. & 2920.23 & $\left(\mathrm{str}^{\mathrm{as}}\right) \mathrm{CH}_{2}$ & Lipids ${ }^{(5)}$ & Methylene group \\
\hline 4. & 2851.21 & (str) $\mathrm{CH}_{2} /-\mathrm{CH}_{3}$ & Lipids $(4,5)$ & $\begin{array}{l}\text { Methyl and Methylene groups in fatty } \\
\text { acids. }\end{array}$ \\
\hline 5. & 1658.97 & (str) $\mathrm{C}=\mathrm{O}$ & Amide $I^{(1-8)}$ & $\begin{array}{l}\text { Protein (mostly } \beta \text {-helical structure; } \\
\text { the secondary structure of the protein } \\
\text { can affect the position }-1695 \text { to } 1637 \\
\mathrm{~cm}^{-1(4)} \text { ) }\end{array}$ \\
\hline 6. & 1641.08 & (str) $\mathrm{C}=\mathrm{O}$ & Amide $I^{(1-8)}$ & $\begin{array}{l}\text { Protein (mostly } \beta \text {-helical structure; } \\
\text { the secondary structure of the protein } \\
\text { can affect the position - } 1695 \text { to } 1637 \\
\mathrm{~cm}^{-1(4)} \text { ) }\end{array}$ \\
\hline 7. & 1629.64 & (str) $\mathrm{O}-\mathrm{H}$ & Water $^{(10)}$ & Water \\
\hline 8. & 1214.76 & (str) $\mathrm{C}-\mathrm{O}$ & Polysaccharides ${ }^{(2,4,9)}$ & $\begin{array}{l}\text { Dominated by ring vibrations in } \\
\text { polysaccharides }\end{array}$ \\
\hline 9. & 1068.13 & (str) $\mathrm{C}-\mathrm{O}$ & Polysaccharides ${ }^{(2,4,9)}$ & $\begin{array}{l}\text { Main region for carbohydrate peaks, } \\
\text { dominated by ring vibrations in } \\
\text { polysaccharides }\end{array}$ \\
\hline
\end{tabular}

Str= stretching, as= asymmetric; 1: Hendrick et al., (1991); 2: Zeroual et al., (1995); 3: Williams and Fleming (1996); 4: Nauman et al., (1996); 5: Sturat and Ando (1997); 6: Lewis and Mcelhaney (1996); 7: Giordano et al., (2001); 8: Nelson (1991); 9: Wong et al., (1991); 10: Sokrates (2001); 11: Keller (1986).

Fig.1 pH recorded from the water samples of the saline alkaline Lake Lonar

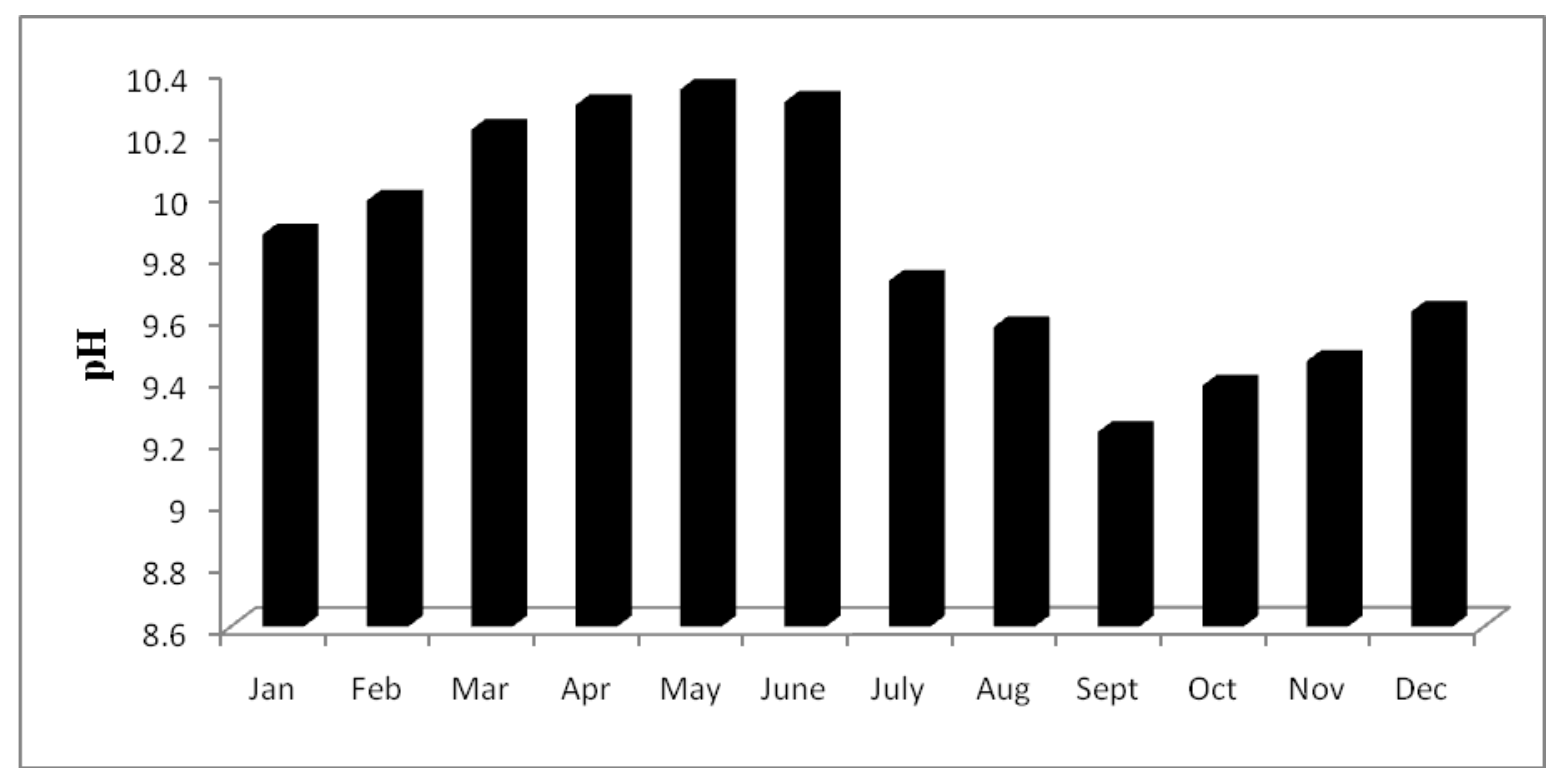


Fig.2 Combined effect of $\mathrm{NaCl}$ and carbonates on Chl.a, the total molarity of the medium was kept at 1M. 1- $0.2 \mathrm{M} \mathrm{Na}_{2} \mathrm{CO}_{3}+0.8 \mathrm{M} \mathrm{NaCl}, 2-0.4 \mathrm{M} \mathrm{Na}_{2} \mathrm{CO}_{3}+0.6$ $\mathrm{M} \mathrm{NaCl}, 3-0.6 \mathrm{M} \mathrm{Na}_{2} \mathrm{CO}_{3}+0.4 \mathrm{M} \mathrm{NaCl}, 4-0.8 \mathrm{M} \mathrm{Na}_{2} \mathrm{CO}_{3}+0.2 \mathrm{M} \mathrm{NaCl}$

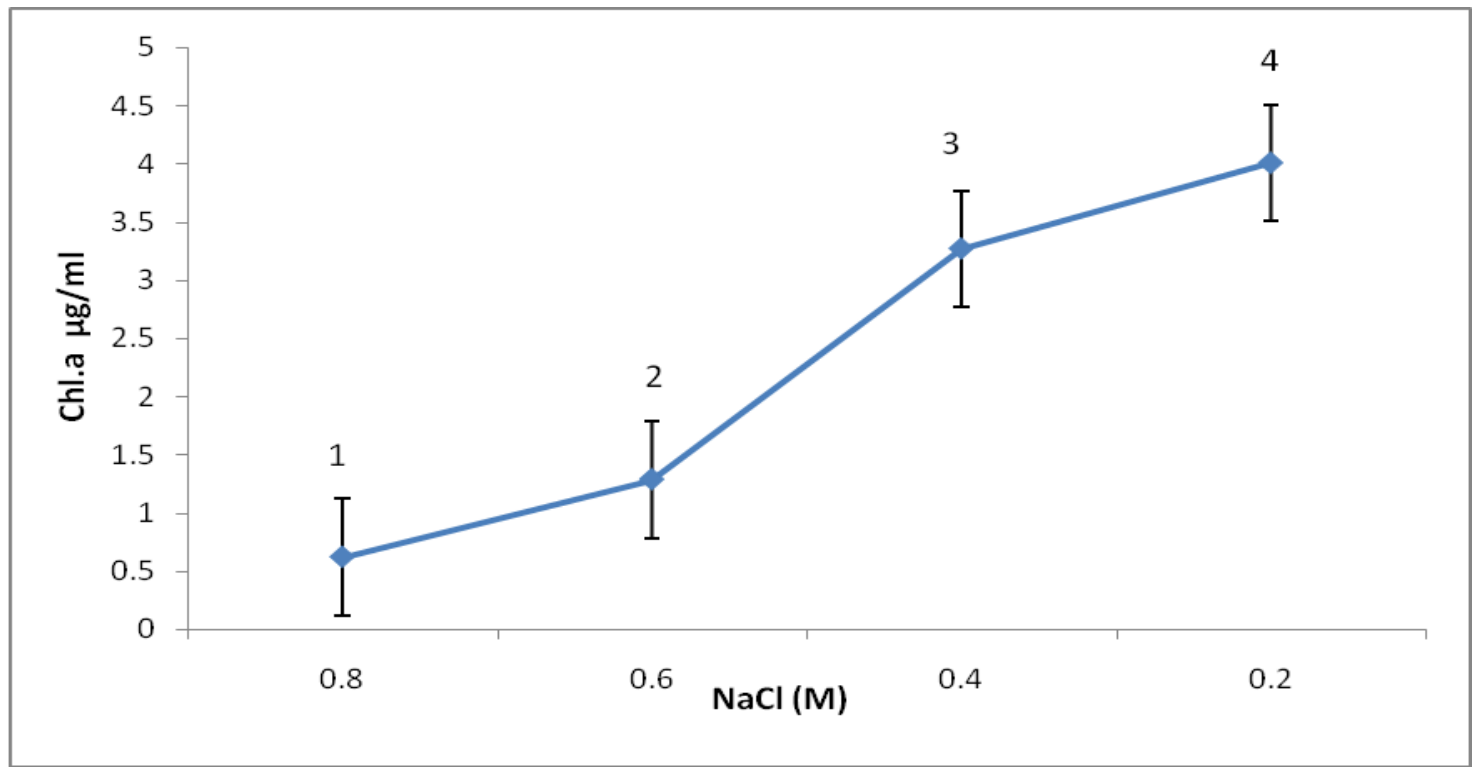

Fig.3 Combined effect of $\mathrm{NaCl}$ and carbonates on $\mathrm{PC}$, the total molarity of the medium was kept at 1M. 1- 0.2 $\mathrm{M} \mathrm{Na}_{2} \mathrm{CO}_{3}+0.8 \mathrm{M} \mathrm{NaCl}, 2-0.4 \mathrm{M} \mathrm{Na}_{2} \mathrm{CO}_{3}+0.6 \mathrm{M} \mathrm{NaCl}, 3-0.6 \mathrm{M} \mathrm{Na}_{2} \mathrm{CO}_{3}+0.4$ $\mathrm{M} \mathrm{NaCl}, 4-0.8 \mathrm{M} \mathrm{Na}_{2} \mathrm{CO}_{3}+0.2 \mathrm{M} \mathrm{NaCl}$

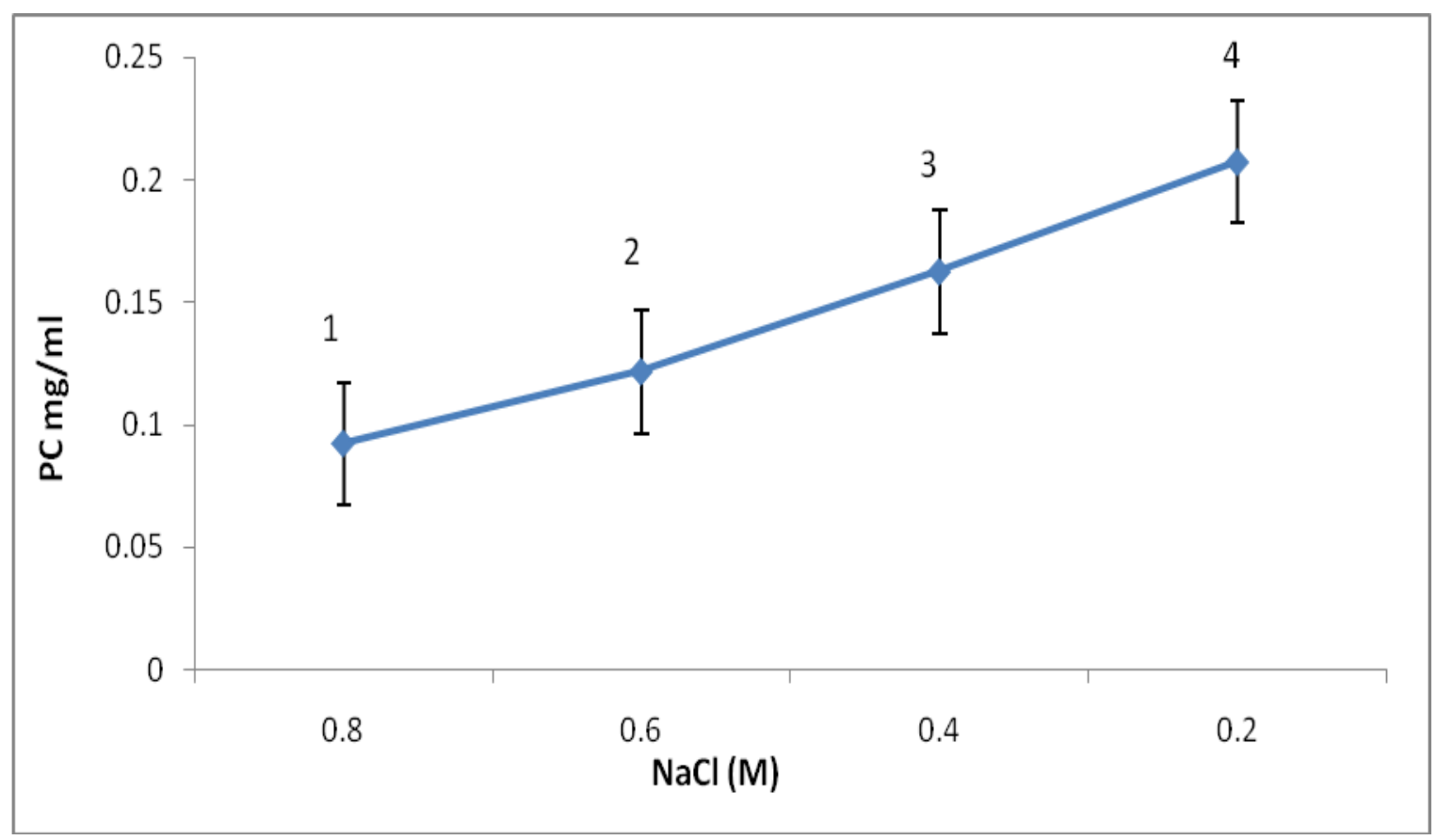


Fig.4 The FTIR- Spectra of the purified sheath of Phormidium sp. at $1 \mathrm{M} \mathrm{Na}_{2} \mathrm{CO}_{3}$

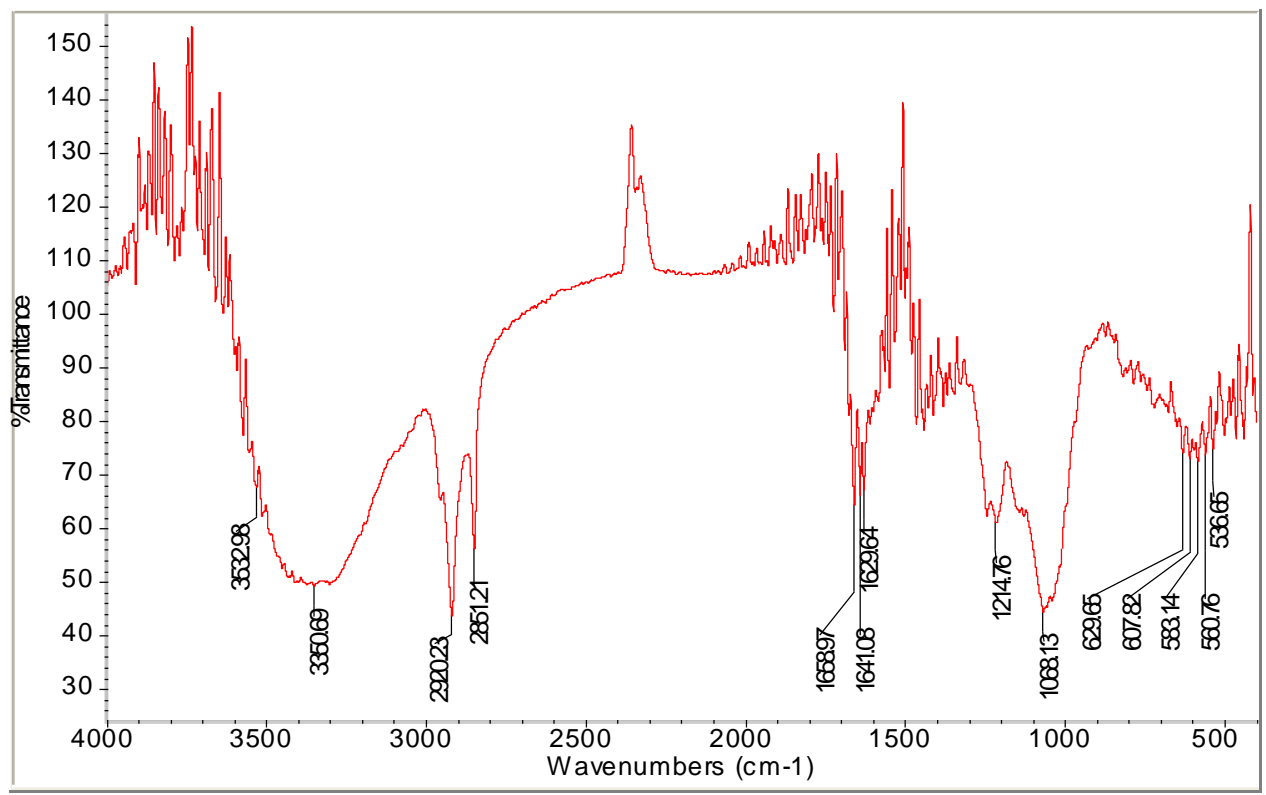

Fig.5 Amount of $\mathrm{Na}_{2} \mathrm{CO}_{3}$ left in the medium at varying $\mathrm{pH}$. The total carbonate concentration of the medium in each flask is $1 \mathrm{M}$

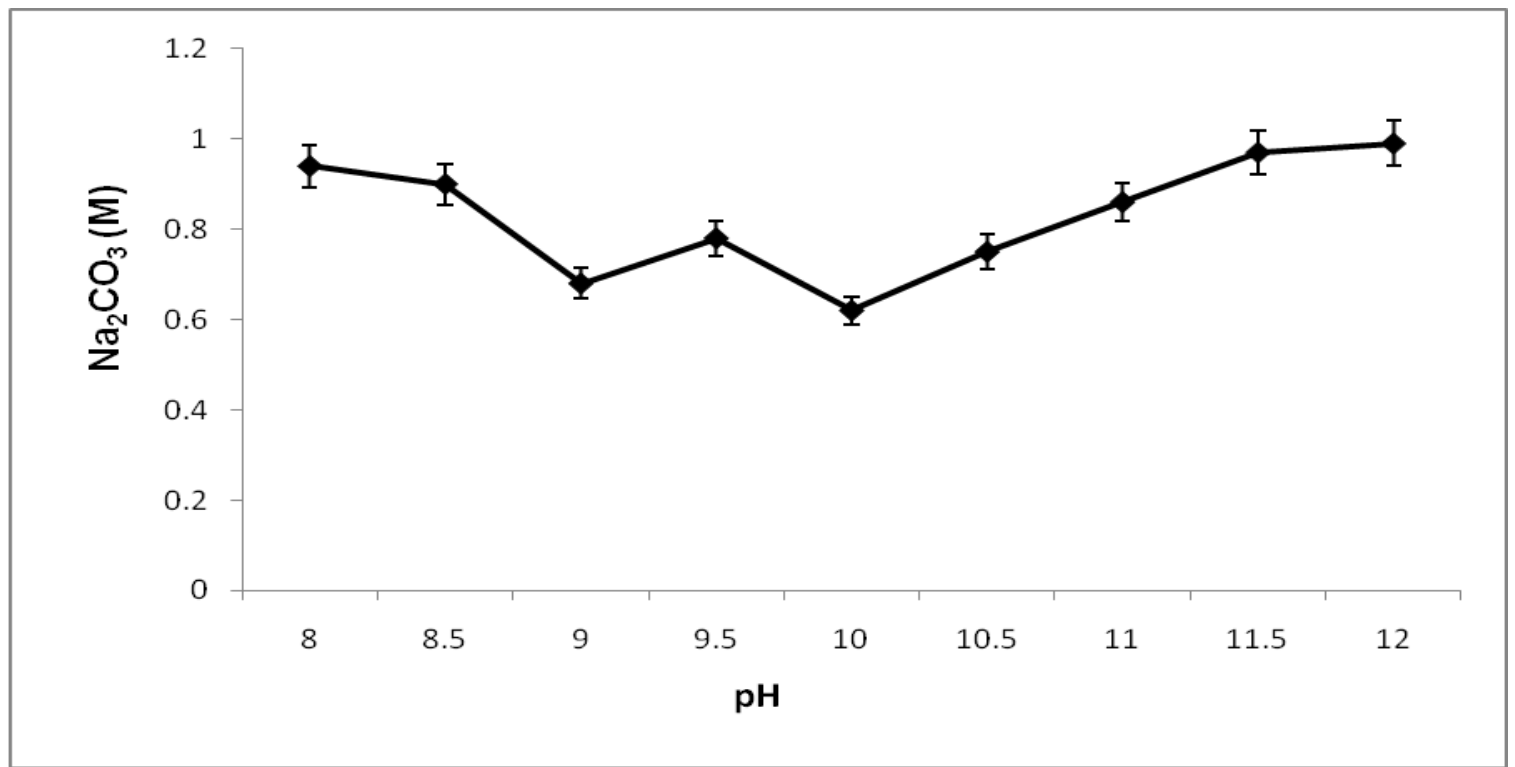

In alkaliphilic cyanobacteria, the intracellular $\mathrm{pH}$ remains stable upon change in the $\mathrm{pH}$ of the medium. Thus change in the $\mathrm{pH}$ level of the medium do not significantly affect the intracellular metabolic processes, but primarily affect processes occurring in the near cellular space and in cell membranes (e.g. carbonate transport). Difference between the internal $\mathrm{pH}$ and environmental $\mathrm{pH}$ affect the transportation of ions and substances through the cell membrane. Thus the alkaliphily is associated with the cell surface (Kupriyanova et al., 2003). In this study it was observed that at $\mathrm{pH} 9$ and 10 there was a 
significant decrease in the remaining carbonate concentration in the medium i.e. 0.68 and 0.62 $M$ respectively (Fig. 5). This suggest that the Phormidium sp isolated from Lonar Lake contains two carbonate transport systems, one of it operates at $\mathrm{pH} 9$ and the other at $\mathrm{pH} 10$. Similar reports of two carbonate systems were observed by Mikhodyuk et al., (2008) in Euhalothece sp. isolated from Lake Magadi.

Presence of more than one transport systems points to the fact that the cyanobacteria residing in the saline alkaline Lonar Lake experience a fluctuation in the carbonate concentration due to desalinization during rainy season. This is the reason that the two transport systems found in the Phormidium sp isolated from Lonar Lake differ in their $\mathrm{pH}$ optima. During the process of desalinization the $\mathrm{pH}$ may shift to lower values (Alcocer et al., 1999). Thus during the rainy season as desalinization takes place the TS-I, whose $\mathrm{pH}$ optima is lower, becomes the main transport system and during the period of drought the carbonate content in the lake increases which results in the increase in the $\mathrm{pH}$ level. Under these conditions the TS-II becomes the dominant transport system. Thus the alkaliphilism or adaptation of cyanobacteria in the alkaline lake lonar depends on the seasonal salinization and desalinization cycles.

\section{Acknowledgement}

The author Devendra V. Deshmukh is thankful to University Grants Commission, New Delhi for providing Junior Research Fellowship under Research Fellowship in Science for Meritorious Students (RFSMS) Scheme.

\section{References}

Alcocer, J., Escobar, E.G., Lugo, A., Oseguera, L.A., 1999. Benthos of a PerenniallyAstatic, Saline, Soda Lake in Mexico, Int. J. Salt Lake Res., 113-126.

APHA. 1995. Standard Methods for the Examination of Water and Waste Water, $19^{\text {th }}$ (eds) American Public Health Association Washington, D.C.
Badger, M.R., Price, G.D., Long, B.M., Woodger, F.J. 2006. The Environmental Plasticity and Ecological Genomics of the Cyanobacterial $\quad \mathrm{CO}_{2} \quad$ Concentrating Mechanism, J. Exp. Bot., 2: 249-265.

Boquet, E., Boronat, A., Ramos-Cormenzana, A. 1973. Production of calcite (calcium carbonate) crystals by soil bacteria is a general phenomenon, Nature, (Lond.) 246: 527-529.

Brandenburg, K., Seydel, U. 1996. Fourier Transform infrared spectroscopy of cell surface polysaccharides. In: $\mathrm{H}$. $\mathrm{H}$. Mantsch and D. Chapman (Eds) Infrared spectroscopy of biomolecules. New York: Wiley-Liss, 203-238.

Castanier, S., Métayer-Levrel, G. Le., Perthuisot, J.P. 1999. Ca-carbonates precipitation and limestone genesis - the microbiologist point of view. Sediment Geol., 126: 9-23.

Desikachary, T.V. 1959. Cyanophyta. New Delhi, India: Indian Council of Agri. Res.

Diem, M., 1993. Introduction to Modern Vibrational Spectrscopy. Wiley Intercience, New York.

Douglas, S., Beveridge, T.J., 1998. Mineral formation by bacteria in natural microbial communities. FEMS Microbiol. Ecol., 26: 79-88.

Ferrer, R.M., Quevedo-Sarmiento, J., Rivadeneyra, M.A., Bejar, V., Delgado, R., Ramos- Cormenzana, A. 1988. Calcium carbonate precipitation by two groups of moderately halophilic microorganisms at different temperatures and salt concentrations. Curr. Microbiol., 17: 221-227.

Garcia-Pichel, F., Nubel, U., Muyzer, G. 1998. The Phylogeny of Unicellular, Extremely Halotolerant Cyanobacteria. Arch. Microbiol, 169: 469-482.

Grant, W.D. 2004. Alkaline Environments and Biodiversity. In C. Gerday and N

Glansdorff. (eds.), Extremophiles. Encyclopedia of Life Support Systems (EOLSS), Eolss Publishers, Oxford, UK.

Grant, W.D., Tindall, B.J., 1980. The isolation of alkaliphilic bacteria. In GW Gould and 
CLI Corry (eds.), Microbial Growth and Survival in Extremes of Environment Academic Press, London, 27-36.

Jhingran, A.G., Rao, K.V. 1954. Rec. Geol. Surv. India, 85: 313-334.

Joshi, A.A., Kanekar, P.P., Kelkar, A.S., Shouche, Y.S., Wani, A.A., Borgave, S.B., Sarnaik, S.S. 2008. Cultivable bacterial diversity of alkaline lonar lake, India. Microb. Ecol., 55: 163-172.

Kaushik, B.D. 1987. Laboratory methods for blue-green algae. New Delhi associated Publication Company, New Delhi.

Kile, D.E., Eberl, D.D., Hoch, A.R., Reddy, M.M. 2000. An assessment of calcite Crystal growth mechanisms based on crystal size distributions. Geochim Cosmochim Acta, 64: 2937-2950.

Kupriyanova, E.V., Lebedeva, N.V., Dudoladova, M.V., Gerasimenko, L.M., Alekseeva, S.G., Pronina, N.A., Zavarzin, G.A. 2003. Carbonic Anhydrase Activity of Alkalophilic Cyanobacteria from Soda Lakes. Russ. J. Plant Physiol., 4: 532539.

Mikhodyuk, O.S., Zavarzin, G.A., Ivanovsky, R.N. 2008. Transport Systems for Carbonate in the Extremely Natronophilic Cyanobacterium Euhalothece sp. Microbiol., 4: 412-418.

Miller, A.G., Turpin, D.H., Canvin, D.T., 1980. $\mathrm{Na}^{+} \quad$ Requirement for Growth, Photosynthesis, and pH Regulation in the Alkalotolerant Cyanobacterium Synechococcus leopoliensis. Plant Physiol., 65: 397-402.

Morita, R.Y. 1980. Calcite precipitation by marine bacteria. Geomicrobiol. J., 2: 6382.
Panick, G., Winter, R., 2000. Pressure-Induced Unfolding/Refolding of Ribonuclease A: Static and Kinetic Fourier Transform Infrared Spectroscopy Study. Biochem. 7: $1862-1869$.

Peckman, J., Paul, J., Thiel, V. 1999. Bacterially mediated formation of diagenetic aragonite and native sulphur in Zechstein carbonates (Upper Permian, Central Germany). Sediment. Geol., 126: 205-222.

Raven, J.A. 1970. Exogenous inorganic carbon sources in plant photosynthesis. Biol. Rev., 45: 167-221.

Rivadeneyra, M.A., Delgado, R., Del Moral A., Ferrer, R.M., 1994. A RamosCormenzana Precipitation of calcium carbonate by Vibrio spp. from an inland saltern. FEMS Microbiol. Ecol., 13: 197-204.

Stuart, B., Ando, D.J. 1997. Biological applications of infrared spectroscopy. ACOL publication (University of Greenwich) Wiley: Chichester.

Thakker, C.D., Ranade, D.R. 2002. An alkalophilic Methanosarcina isolated from Lonar crater. Curr. Sci., 82: 455458.

Ulukanli, Z., Digrak, M., 2002. Alkaliphilic microorganisms and habitats. Turk. J. Biol., 26: 181-191.

Yates, K.K., Robbins, L.L. 1999. Radioisotope tracer studies of inorganic carbon and $\mathrm{Ca}$ in microbiologically derived $\mathrm{CaCO}_{3}$. Geochim. Cosmochim. Acta, 63: 129-136.

Zeroual, W., Manfait, M., Choisy, C. 1995. FTIR spectroscopy study of perturbations induced by antibiotic on bacteria. Pathologie et Biologie, 43: 300-305.

\section{How to cite this article:}

Devendra Deshmukh and Pravin Puranik. 2017. Alkaliphilism and Carbonate Transport in Alkaliphilic Cyanobacteria (Phormidium sp.) Isolated from Alkaline Lake Lonar, India. Int.J.Curr.Microbiol.App.Sci. 6(2): 397-405. doi: http://dx.doi.org/10.20546/ijcmas.2017.602.044 